\title{
Histological and Immunohistochemical Study on the Effect of Valporic Acid on the Femur of Adult Male Guinea Pigs and the Possible Protective Role of L-carnitine

Histology Department, Faculty of Medicine; Menoufia University, Egypt

\begin{abstract}
Background: Valporic acid (VPA) is a broad-spectrum antiepileptic drug and is effective in the treatment of different types of epileptic seizures. It usually affects bone and mineral metabolism and increase the risk of fractures due to decreased bone mineral density (BMD). Among dietary supplements, L-carnitine is an emergic candidate with potential bone protective effects. It promotes energy utilization and is important for tissues with high energy requirements.

Objective: The target of this work is to estimate the effect of valproic acid on the femur and the possible protective effect of L-carnitine administration in adult male guinea pigs.

Materials \& Methods: Forty adult male guinea pigs were utilized in the current study. The guinea pigs were divided into four groups, Group I (control group), Group II(L-carnitine treated group), Group III (Valporic acid treated group) and Group IV (L-carnitine and valporic acid treated group). After 10 weeks, the upper parts of femur were processed for histological, morphological and immunohistochemical studies.

Results: Valporic acid treated group was associated with enhanced bone turnover as evident by a significant change in serum levels of calcium, osteocalcin and TRAP. Moreover, there was a significant decrease in trabecular and cortical bone thickness and a significant change in the mean number of osteoclasts and osteoblasts. Histologically, evidence of bone resorption was manifested in the femoral bone with resorption cavities, irregular endosteal surface. Decrease of collagen in the cortical bone was evident in trichrome-stained sections. Immunohistochemically, this group showed positive immunoreactivity for caspase-3 in osteocytes and decrease in osteopontin expression in bone matrix. L-carnitine supplementation with valporic acid in group IV has ameliorating effect on the histological abnormalities of bone.

Conclusion: L-carnitine improved the biochemical, histological and morphometric changes induced by VPA, and therefore, there is a potential benefit in using L-carnitine with long term administration of valporic acid.
\end{abstract}

Received: 05 November 2019, Accepted: 16 December 2019

Key Words: Bone, L-carnitine, valporic acid.

Corresponding Author: Amira Fahmy, M.D, Histology Department, Faculty of Medicine; Menoufia University, Egypt, Tel.: +20 1068915402, E-mail: amirafahmy356@yahoo.com

ISSN: $1110-0559$, Vol. 43, No.3

\section{INTRODUCTION}

Epilepsy is the most common chronic neurological disorders, distinguished by recurrent epileptic seizures. The disease affects more than 70 million people worldwide $^{[1]}$. The cause of most cases of epilepsy is unknown. Some cases occur as a result of brain injury, stroke, brain tumors, infection or birth defects through a process known as epileptogenesis. Epileptic seizures are the result of excessive and abnormal neuronal activity in the cortex of the brain and they are classified as either focal or generalized based on the abnormal activity appear in just one area or involve all areas of the brain respectively. Epilepsy usually requires long-term antiepileptic drugs (AEDs) including valporic acid ${ }^{[2]}$.

Valporic acid (VPA) is widely used antiepileptic medicine and has a broad spectrum of anticonvulsant action, it is also used in the treatment of various conditions such as migraine headaches and manic phase of bipolar disorder ${ }^{[3]}$. It works by influencing GABA levels and blocking voltage-gated sodium channels ${ }^{[4]}$.
VPA has fewer side effects than do others AEDs. Furthermore, its harmful effects could often be reduced by intiating the drug slowly. However severe complications might happen in some patients taking VPA for a long time, such as encephalopathy, haemorrhagic pancreatitis and bone marrow suppression ${ }^{[5]}$.

It was also reported that, long term VPA therapy started to be correlated with low bone mineral density, increase in fracture risk and abnormalities in bone metabolism ${ }^{[6]}$.

L-carnitine supplements are taken to raise level of L-carnitine in individuals whose natural level of L-carnitine is too low because they are taking certain drugs as valproic acid for epilepsy, have a genetic disorder or because they are undergoing a medical procedure as hemodialysis for renal disease that uses up the body's L-carnitine ${ }^{[7]}$.

L-carnitine is an amino acid that is produced in the body naturally. It helps the body convert lipid into energy and is important for tissues with high energy requirements such 
as muscle and bone ${ }^{[8]}$. The body could modify L-carnitine to other amino acids named propionyl-L-carnitine and acetyl-L-carnitine ${ }^{[9]}$.

It has been stated that, L-carnitine displays a direct influence on increasing osteoblast activity and proliferation, as well as the expression of collagen type $\mathrm{I}^{[10]}$. L-carnitine could affect bone density and slow the bone turnover rate ${ }^{[11]}$. Lately, L-carnitine shown to have antioxidant activity counteracting age-associated mitochondrial dysfunction and to keep the balance of mitochondrial production of Reactive Oxygen Species (ROS) in different cells type ${ }^{[12]}$. Therefore, this study pointed to evaluate the influence of valporic acid on the femur and the possible protective effect of L-carnitine administration in adult male guinea pigs.

\section{MATERIALS AND METHODS}

\section{Drugs}

Valporic acid: depakene, it is available as oral solution $250 \mathrm{mg} / 5 \mathrm{ml}$, manufactured by Sanofi Aventis, Berlin, Germany

L-carnitine: It is available as oral solution, $300 \mathrm{mg} / 100$ ml, manufactured by Sigma Aldrich Company (St. Louis, MO, USA).

\section{Animals}

Forty adult male guinea pigs, weighting 400-500g were employed in the present work. Researchers found that guinea pigs are the best experimental model to study epileptic activity in the brain and they offer experimental advantages not achieved with use of other experimental $\operatorname{model}^{[13]}$. They were housed at room temperature in stainless steel cages. The guinea pigs had free access to food and water ad-libitum. Strict hygiene was followed to keep a healthy medium for the guinea pigs. All animals protocols were approved and observed via the Animal Care Committee of the Research Laboratory of Experimental Animals at the College of Medicine, Menoufia university, Egypt.

\section{Experimental protocol}

The guinea pigs were divided into four groups, each included 10 guinea pigs.

Group I (control group): The guinea pigs were held without treatment throughout the experiment.

Group II (L-carnitine treated group): The guinea pigs received L-carnitine $200 \mathrm{mg} / \mathrm{kg} / \mathrm{d}$ by oral gavage for 10 weeks $^{[14]}$.

Group III (Valporic acid treated group): The guinea pigs received valporic acid $300 \mathrm{mg} / \mathrm{kg} / \mathrm{d}$ by oral gavage for 10 weeks $^{[15]}$.

Group IV (L-carnitine and valporic acid treated group): The animals in this group received L-carnitine along with valporic acid similarly to groups II \& III respectively for 10 weeks.
$24 \mathrm{~h}$ after the last dose of drugs administration, ether inhalation was used to anaesthetize the guinea pigs from all groups. Blood samples were collected into heparin coated tubes for biochemical study. The femurs were dissected from soft tissue ,washed with saline and upper parts of femurs were processed for histological, immunohistochemical and scanning electron microscopic studies.

\section{I- Biochemical study}

Serum concentration of calcium ${ }^{[16]}$ was estimated using an autoanalyzer (Hitachi Co. Ltd, Tokyo, Japan). Serum osteocalcin (a marker of osteoblastic activity) was measured by ElectroChemiLuminescence, Immune Kit (Elecsys and cobas analyzer, Roche, Germany) ${ }^{[17]}$. Serum tartrate-resistant acid phosphatase (TRAP) (a marker of osteoclastic activity) was measured using an enzymatic assay (MK301, Takara, Japan) ${ }^{[18]}$.

\section{II-Histological study}

The upper parts of the right femurs were fixed in formal saline. Then, the bones were decalcified utilizing the chelating agent EDTA. The specimens then were processed for Paraffin sections of about 5-6 $\mu \mathrm{m}$ thickness. Sections were obtained, then stained with hematoxylin and eosin to exhibit the histological structure \& Mallory's trichrome stain to detect the collagen fibers ${ }^{[19]}$.

\section{III-Scanning electron microscopic study}

The upper part of the left femur from each animal was rapidly fixed in $3 \%$ glutraldehyde solution and processed for examination, using Philips Scanning electron microscope (Seo-Russia) in Tanta E.M Center at faculty of medicine, Tanta University ${ }^{[20]}$.

\section{IV-Immunohistochemical study}

\section{Osteopontine immunostaining}

paraffin sections were incubated with a rabbit antiosteopontin (OPN) polyclonal antibody which has cross reactivity with rats (Calbiochem, San Diego, CA, USA), utilizing the avidin biotin peroxidase method to assess osteopontin (OPN) localization in bone. OPN immunoreactivity with strong staining apparent in cement lines, osteoblasts, osteocytes, canaliculi, osteoid and bone matrix. Negative control sections were processed by replacing the primary antibody with buffer alone . Osteosarcoma was used as a positive control ${ }^{[21]}$.

\section{Caspase-3 immunostaining}

Paraffin sections were incubated with primary antibody. Activated caspase- 3 expression was estimated utilizing a peroxidase-conjugated rabbit monoclonal antibody IgG (Cell signaling Technology, Ipswich, MA) (dilution 1:200). Negative control sections were processed by replacing the primary antibody with buffer alone. Normal lymphoid tissue was utilized as a positive control ${ }^{[22]}$. 


\section{V-Morphometrical study and Statistical analysis}

H\&E femur sections from all guinea pigs groups were observed under light microscopy at magnification of 400 via utilizing the interactive measuring menu of image analyzer (Lecia Qwin 500 image analyzer computer system, England) in anatomy department, faculty of medicine, Menoufia University. The outer cortical bone thickness and trabecular bone thickness were measured in $\mu \mathrm{m}$. The number of osteoblast and osteoclast were measured in 10 fields of each specimen.

The biochemical and morphometric results were analyzed and compared by student's t-test. The p-value was utilized to test the significant change in the experimental groups in each parameter in comparison with the control group. The data were tabulated as mean $\pm \mathrm{SD}$ and analyzed utilizing statistical package for the Social Science Software (SPSS) (version 17.0 on an IBM compatible computer; SPSS Inc., Chicago, Illinois, USA). $P$ value was set at $0.05, P>0.05$ non-significant, $P$ value $<0.05$ significant and $P$ value $<0.001$ highly significant ${ }^{[23]}$.

\section{RESULTS}

\section{General appearance of the animals}

The animals of all groups were in good general condition and showed normal behavior, activity and apatite, except valproic acid treated animals showed decreased activity and one animal died during experiment.

\section{Biochemical results}

As shown in (Table 1), L-carnitine treated guinea pigs (group II) revealed a non-significant changes in serum levels of calcium, osteocalcin and TRAP $(P>0.05)$ when compared with the control group (group I). Valporic acid treated group (group III) exhibited a significant decrease $(P<0.05)$ in serum calcium and a highly significant decrease $(P<0.001)$ in serum osteocalcin and a highly significant increase $(P<0.001)$ in serum tartrate-resistant acid phosphatase (TRAP) level in comparison with the animals of control group. Moreover, L-carnitine and valporic acid treated group (group IV) revealed a nonsignificant $(P>0.05)$ changes in the mean values of serum levels of calcium, osteocalcin and TRAP when compared with the control group. while revealed a significant increase $(P<0.05)$ in serum calcium and osteocalcin levels and a highly significant decrease $(P<0.001)$ in TRAP level when compared with valporic acid treated group (Histogram 1).

\section{Histological results}

H\&E sections of a guinea pig femur of control and L-carnitine groups (groups I\&II) revealed the well-known histological structure. It showed the outer cortical bone that was covered by the periosteum, the compact bone appeared with well-organized external circumferential lamellae, concentric lamella arranged around haversion canals, interstitial (Figures 1,2) and internal circumferential lamellae (Figure 3) . The osteocytes inside their lacunae were seen (Figures 1,2,3). Subperiosteal bone formation appearing as a distinguished basophilic cement line separating between the newly formed matrix and the older bone (Figure 1).

The endosteal surface of the cortical bone seemed smooth and lined by osteoblast cells (Figure 3 ) .

The cancellous bone was formed of multiple bone trabeculae enclosing bone marrow spaces of variable sizes, osteocytes in their lacunae within matrix were seen. The matrix showed basophilic cement lines and areas (Figure 4). Multinucleated osteoclast with multiple nuclei was seen on the trabecular bone surface (Figure 5).

Sections of the femur of guinea pigs of Valporic acid treated group (group III) revealed very thick and highly fibrous periosteum with appearance of irregular cement lines and less acidophilia of matrix (Figure 6). The osteocytes appeared with pyknotic nuclei and increased number of apparent widened empty osteocyte lacunae (Figs. 6,7,8) was seen, multiple cavities surrounded by basophilic cement lines were also observed (Figures 7,8). Moreover, irregular endosteum with erosion cavity containing multiple multinucleated osteoclasts with acidophilic cytoplasm was encountered (Figure 8).

The cancellous bone of this group revealed apparent thinning of the trabeculae with wide bone marrow cavities, eroded area was observed on the bone surface (Figure 9). Multiple areas of faintly stained matrix in bone trabeculae were seen (Figures 9,10). The trabecular bone surface was lined by multiple multinucleated osteoclasts with acidophilic cytoplasm in Howship's lacunae (Figure 10).

Sections of the femur of guinea pigs of L-carnitine and valporic acid treated group (group IV) showed woven bone appeared as pale stained area and a basophilic cement line was observed between the old and the newly formed bone, basophilic area within matrix with newly formed osteocytes was apparent (Figure 11). The cortical bone structure was more or less as in control group. Haversion canals, osteocytes inside their lacunae were seen. Some empty lacunae were observed (Figure 12).

The cancellous bone revealed branching and anastomosing trabeculae of nearly normal thickness and shape with distinct basophilic areas in the trabecular core (Figure 13). Apparent increase in the number of osteoblasts with eccentric nuclei was observed (Figure 14).

Regarding to the Mallory Trichrome stained sections of the femur of control \& L- carnitine treated groups (groups I\&II), it revealed deeply stained blue colored regularly arranged collagen fibers in the cortical bone matrix (Figure 15). While examination of group III (valporic acid treated group) showed lightly stained collagen fibers (blue color), some areas appear pale stained (Figure 16). Moreover, examination of L-carnitine and valporic acid treated group (group IV) revealed regularly arranged collagen fibers (blue color) with small pale stained areas (Figure 17). 
Scanning electron microscopic examination of a femur of control guinea pigs (groups I\&II) revealed bone trabeculae with bone marrow spaces inbetween arising from outer cortical bone. The compact bone containing haversian canals surrounded by osteocyte lacunae were seen, osteoclast cell with ruffled border facing bone surface was observed (Figure 18). Endosteal surface of the compact bone was appeared with endosteal pores, representing Volkmann canals opening (Figure 19). Branching and anastomosing cancellous bone trabeculae with uniform size and shape were seen (Figure 20). A scanning electron microscopic examination of the valporic acid treated guinea pigs (group III) showed broken trabeculae arising from apparently thin compact bone containing apparent widened haversian canal as compared with the control group with appearance of cracks in bone surface (Figure 21). The endosteal surface appeared peeled with wide pores (Figure 22). Thin and broken cancellous bone trabeculae were observed with loss of uniform thickness (Figure 23). A scanning electron microscopic examination of the Group IV (L-carnitine and valporic acid treated group) showed branching and anastomosing bone trabeculae and cortical bone of uniform thickness with appearance of epiphyseal plate (Figure 24).

\section{Immunohistochemical results}

Osteopontin immunostaining: Sections of a guinea pig femur at compact bone of group I (control group) showed marked positive reaction of osteopontin protein, expressed as brown granules in bone matrix and negative expression in the other bone components (Figure 25). Valporic acid treated group showed marked decrease in osteopontin expression in bone matrix (Figure 26). While group IV (L-carnitine and valporic acid treated group) revealed an increase in osteopontin brown immunoreaction in bone matrix more or less as in control animals (Figure 27).

Caspase-3 immunostaining: Sections of a guinea pig femur of group I (control group) revealed negative immunoreactivity for caspase-3 in all cells of the bone (Figure 28). The osteocytes in valporic acid treated group showed positive cytoplasmic immunoreactivity in the form of brown granules for this staining (Figure 29). While in group IV (L-carnitine and valporic acid treated group), the osteocytes revealed negative cytoplasmic immunoreactivity for caspase-3 (Figure 30).

\section{Morphometric results}

Data in (Table 2) demonstrated that valporic acid treated group (group III) exhibited a highly significant increase $(P<0.001)$ in the mean number of osteoclasts and a highly significant decrease $(P<0.001)$ in the mean number of osteoblasts in comparison with the control guinea pigs, while marked improvement with non-significant change $(P>0.05)$ was observed in L-carnitine and valporic acid treated group (group IV) when compared with the control one, moreover, exhibited a highly significant changes $(P<0.001)$ when compared with valporic acid treated group (group III) (Histogram 2).
In addition, valporic acid treated group (group III) exhibited a highly significant decrease $(P<0.001)$ in the cortical bone and trabecular bone thickness when compared with the control group. However, guinea pigs of the L-carnitine and valporic acid treated guinea pigs (group IV) revealed a non significant decrease when compared with the control group and a highly significant increase when compared with the valporic acid treated group (Table 2).

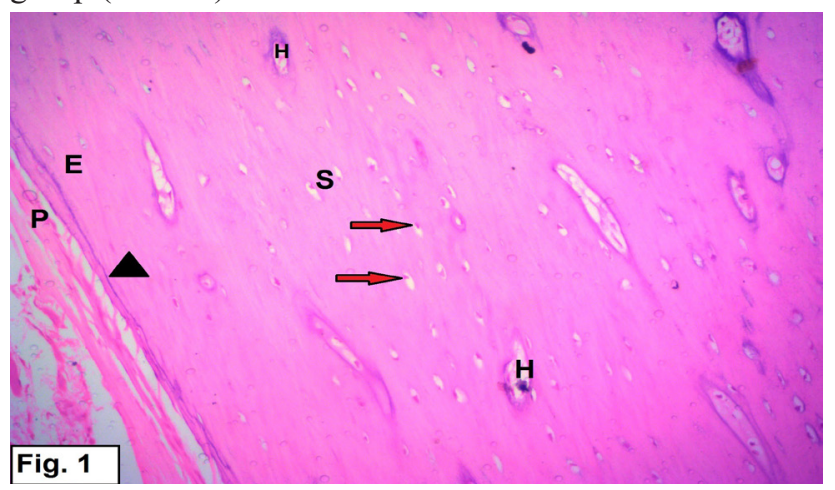

Fig. 1: A photomicrograph of a guinea pig femur of group I (control group) showing the outer part of cortical bone. The bone is covered from outside by periosteum $(\mathrm{P})$. The compact bone is organized in the form of external circumferential lamella (E), concentric lamella arranged around haversian canals $(\mathrm{H})$ and interstitial lamellae (S). The osteocytes (red arrows) inside their lacunae are seen. Notice, subperiosteal bone `formation appearing as a distinghised basophilic cement line (arrowhead). Hx\&E X200

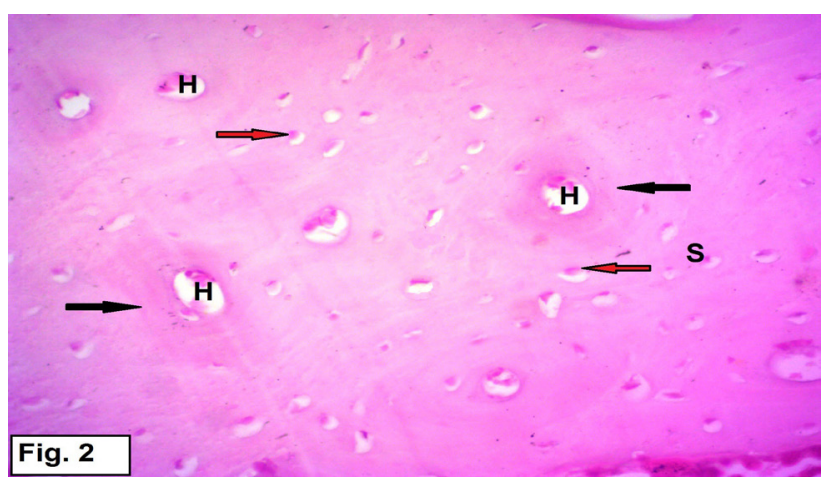

Fig. 2: A photomicrograph of a guinea pig femur of group I (control group) showing concentric lamellae (black arrows) arranged around haversian canals $(\mathrm{H})$, osteocytes (red arrows) inside their lacunae are seen inbetween lamella. Notice, homogenous acidophilic matrix and interstitial lamellae (S). Hx\&E X400

Fig. 3: A photomicrograph of a guinea pig femur of group I (control group) showing the inner part of cortical bone. The endosteum is lined by osteoblast cells (black arrows). Osteocytes (red arrow) inside their lacunae and haversian canals $(\mathrm{H})$ are observed . Notice, inner circumferential lamella (I).Hx\&E X 200 


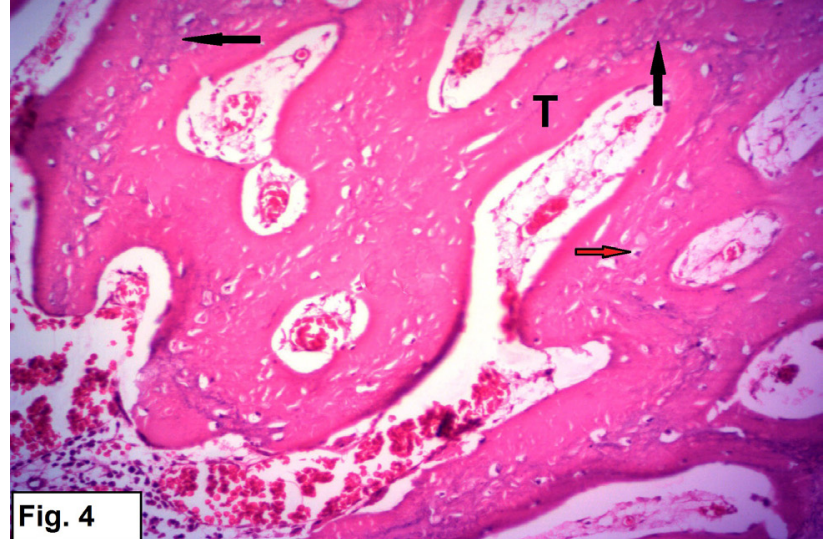

Fig. 4: A photomicrograph of a guinea pig femur of group I (control group) showing multiple bone trabeculae ( $\mathrm{T}$ ) enclosing bone marrow cavities of variable sizes, osteocytes (red arrow)in their lacunae within matrix are seen. Notice, basophilic cement lines and areas (black arrows). Hx\&E X200

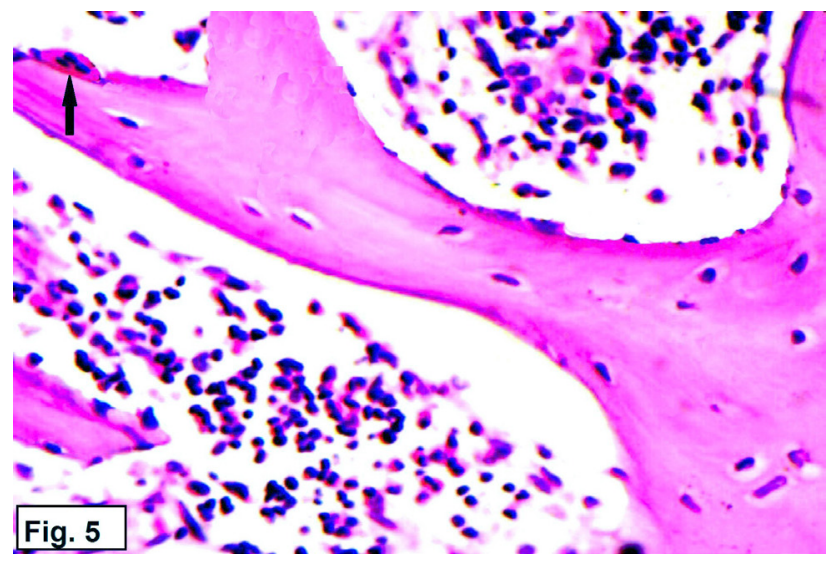

Fig. 5: A photomicrograph of a guinea pig femur of group I (control group) showing multinucleated osteoclast cell with acidophilic cytoplasm on the trabecular bone surface (arrow)Hx\&E X400

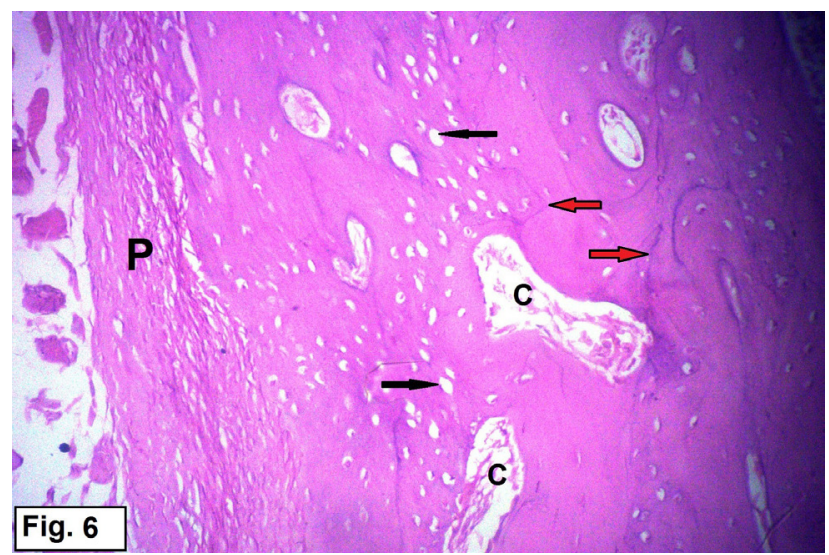

Fig. 6: A photomicrograph of a guinea pig femur of group III (valporic acid treated group) showing very thick and highly fibrous periosteum (P) , multiple cavities (C) containing granulation tissue within matrix and irregularly arranged osteocytes are observed, some lacunae (black arrows) appear empty. Notice, irregular cement lines (red arrows) and less acidophilia of matrix. Hx\&E X200

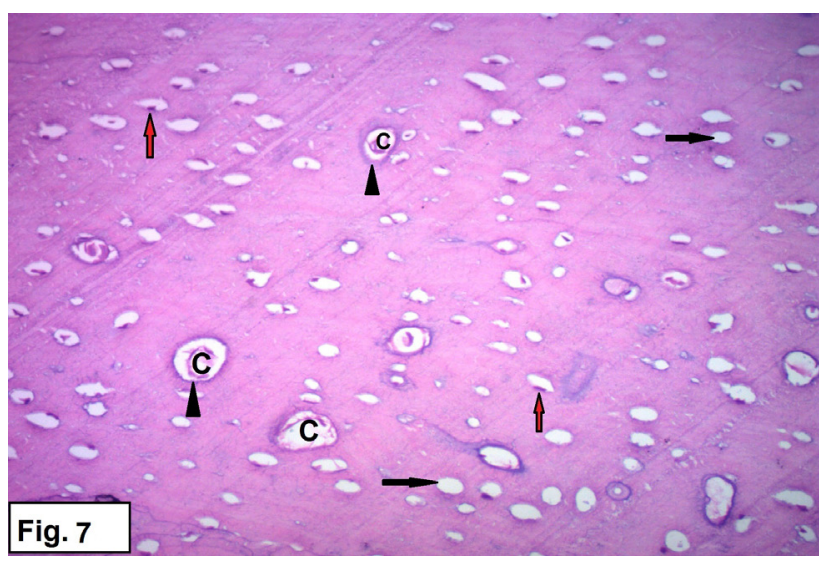

Fig. 7: A photomicrograph of a guinea pig femur of group III (valporic acid treated group) showing osteocytes with pyknotic nuclei (red arrows) and increased number of apparent widened empty lacunae (black arrows) are seen . Notice, cavities (C) in the cortical bone surrounded by basophilic cement lines (arrowheads).Hx\&E X400

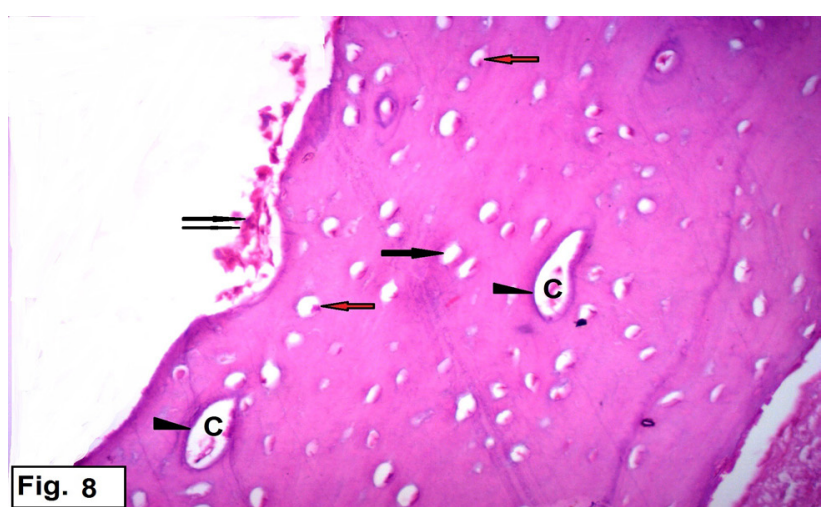

Fig. 8: A photomicrograph of a guinea pig femur of group III (valporic acid treated group) showing degenerated osteocytes (red arrows) in their apparent wide lacunae, some lacunae are empty (black arrow) large cavities (C) surrounded by basophilic cement line (arrowheads) are seen. Notice, irregular endosteum with erosion cavity containing multinucleated osteoclasts with acidophilic cytoplasm(double arrow), Hx\&E X 400

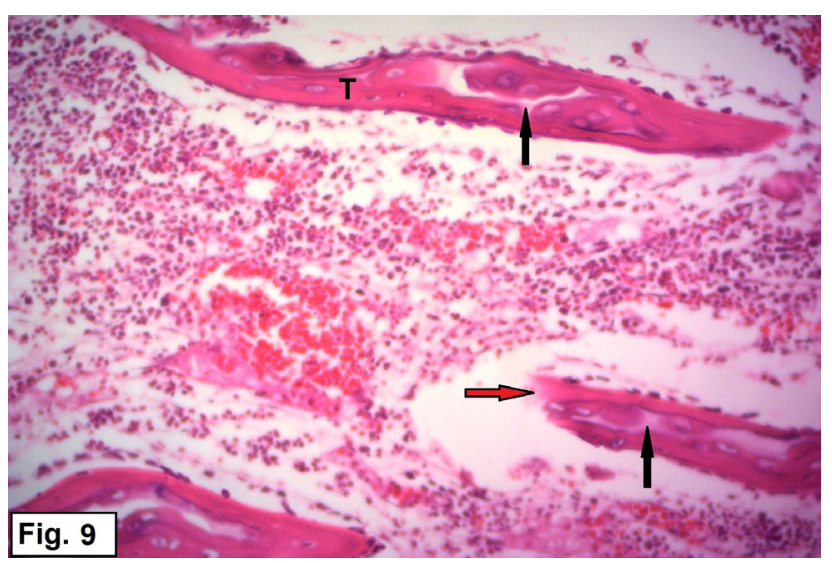

Fig. 9: A photomicrograph of a guinea pig femur of group III (valporic acid treated group) showing apparent thinned out trabeculae $(\mathrm{T})$ with wide bone marrow spaces, multiple areas of faintly stained matrix (black arrows) in bone trabeculae are seen. Notice, the eroded trabecular bone surface (red arrow). Hx\&E X200 


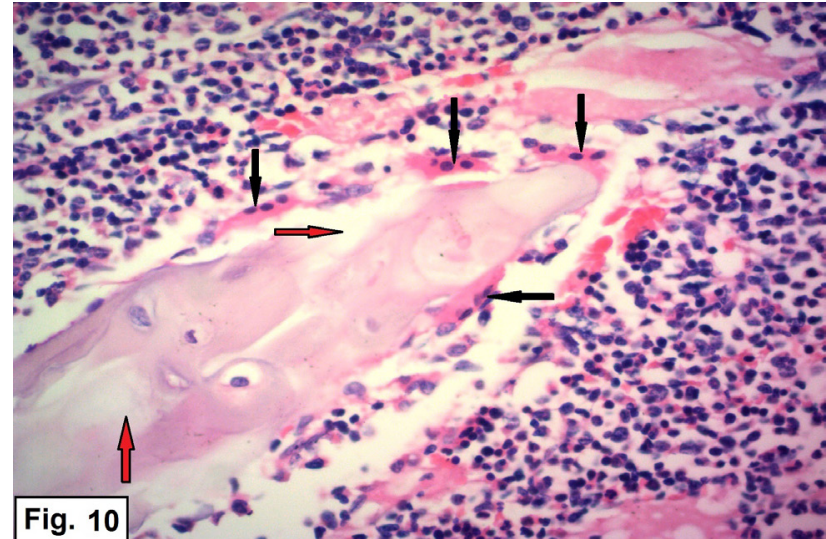

Fig. 10: A photomicrograph of a guinea pig femur of group III (valporic acid treated group) showing multiple multinucleated osteoclasts with acidophilic cytoplasm in Howship's lacunae on the trabecular bone surface (black arrows). Notice, faintly stained matrix in bone trabeculae (red arrows) .Hx\&E X400

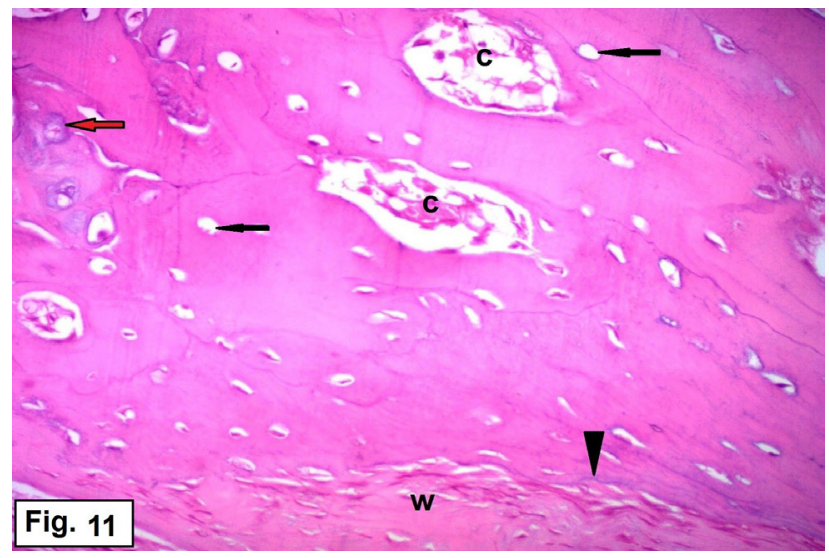

Fig. 11: A photomicrograph of a guinea pig femur of group IV (L-carnitine and valporic acid treated group) showing an area of woven bone (W) that appears as pale stained area and a basophilic cement line (arrowhead) is seen between old and new bone. Some osteocyts lacunae appear empty (black arrow). Notice, basophilic area with nearby newly formed osteocytes (red arrows) and cavities (C).Hx \&E X400

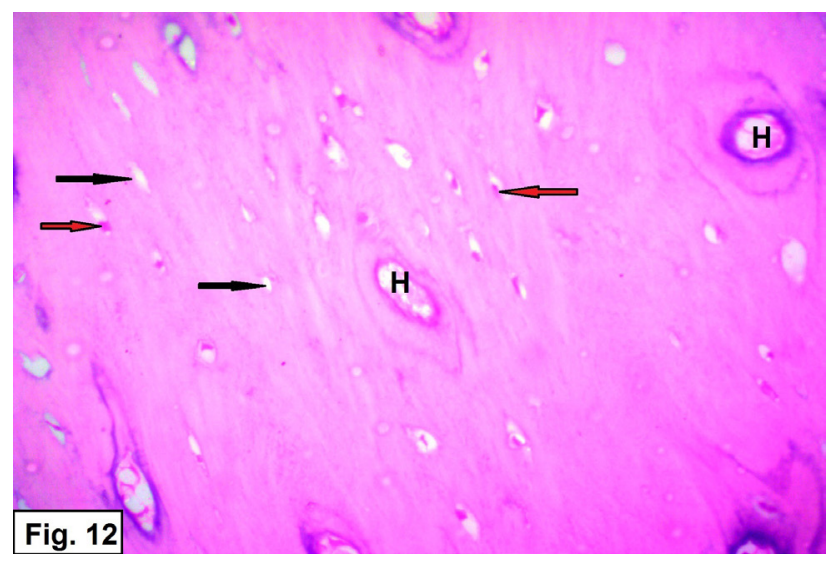

Fig. 12: A photomicrograph of a guinea pig femur of group IV (L-carnitine and valporic acid treated group) showing cortical bone structure which is more or less as control group . Haversion canals $(\mathrm{H})$ and osteocytes (red arrow) inside their lacunae are seen. Notice, appearance of empty lacunae (black arrows).Hx\&E X400

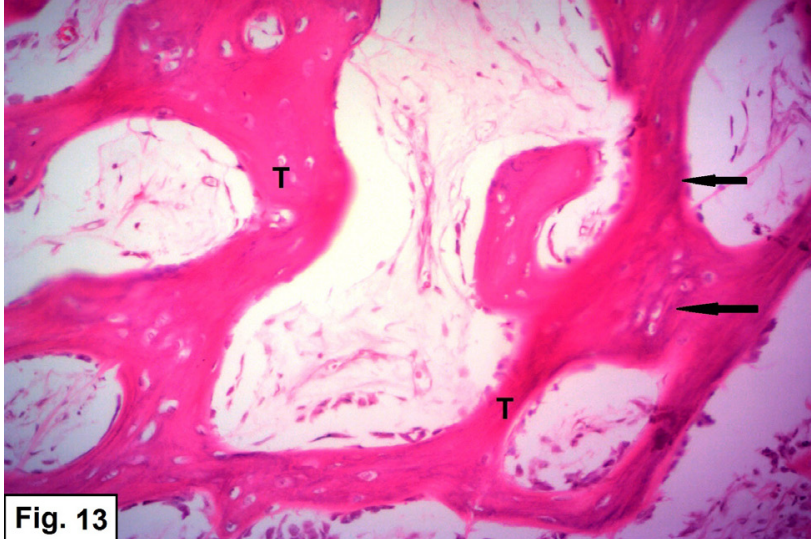

Fig. 13: A photomicrograph of a guinea pig femur of group IV (L-carnitine and valporic acid treated group) showing branching and anastomosing trabeculae (T) of nearly normal thickness and shape with distinct basophilic areas in the trabecular core (arrows) . Hx\&E X200

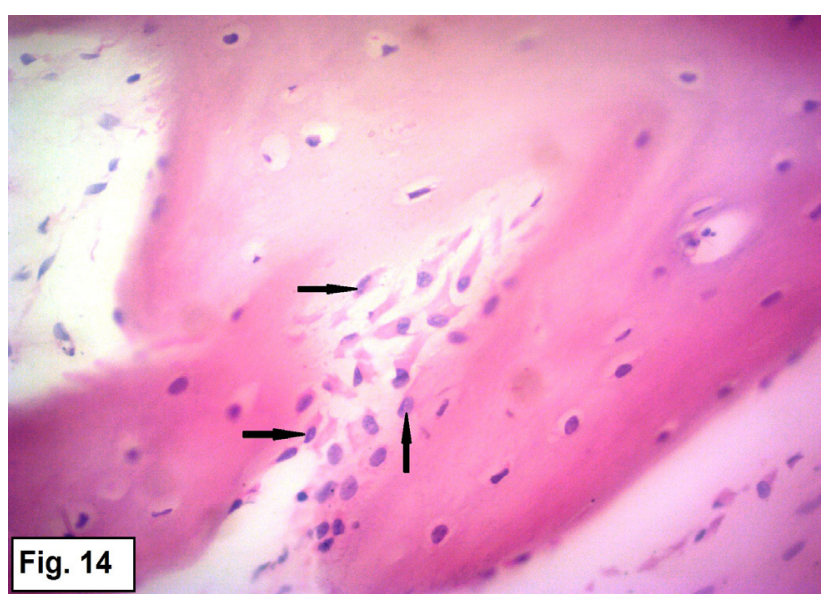

Fig. 14: A photomicrograph of a guinea pig femur of group IV (L-carnitine and valporic acid treated group) showing apparent increase in the number of osteoblast cells with eccentric nuclei (arrows).Hx\&E X400

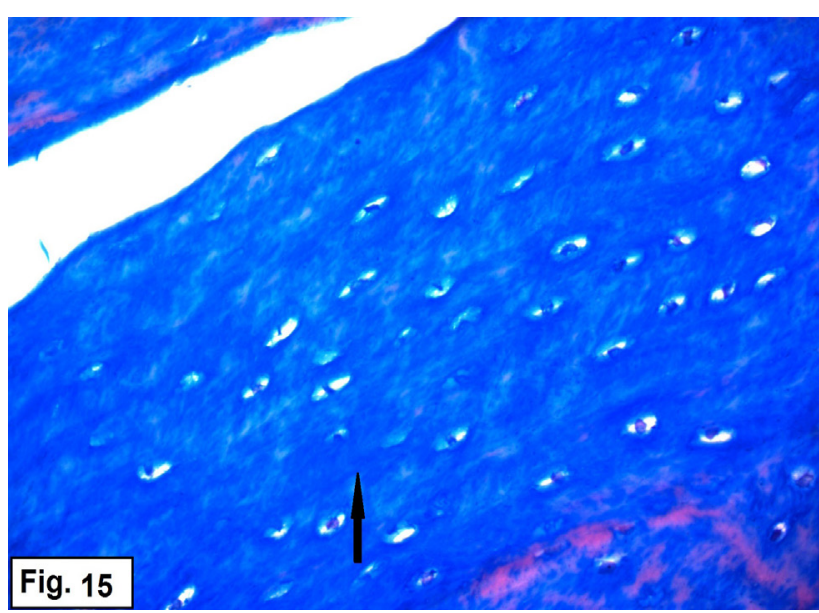

Fig. 15: A photomicrograph of a guinea pig femur of group I (contro group) showing deeply stained blue colored regularly arranged collagen fibers in the cortical bone matrix (arrow).M.T X400 


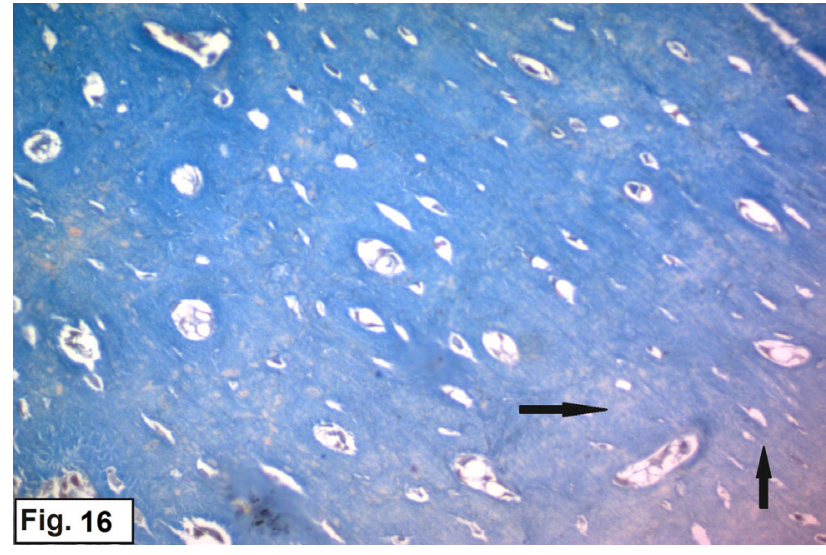

Fig. 16: A photomicrograph of a guinea pig femur of group III (valporic acid treated group) showing lightly stained collagen fibers (blue color). Some areas appear pale stained (arrows). 400M.T X

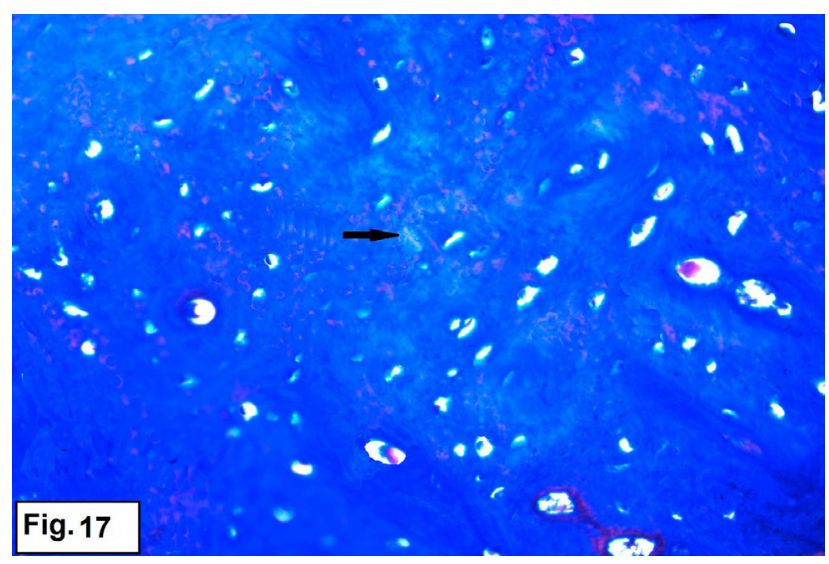

Fig. 17: A photomicrograph of a guinea pig femur of group IV (L-carnitine and valporic acid treated group)showing regularly arranged collagen fibers (blue color) with small pale stained areas (arrow).400M.TX

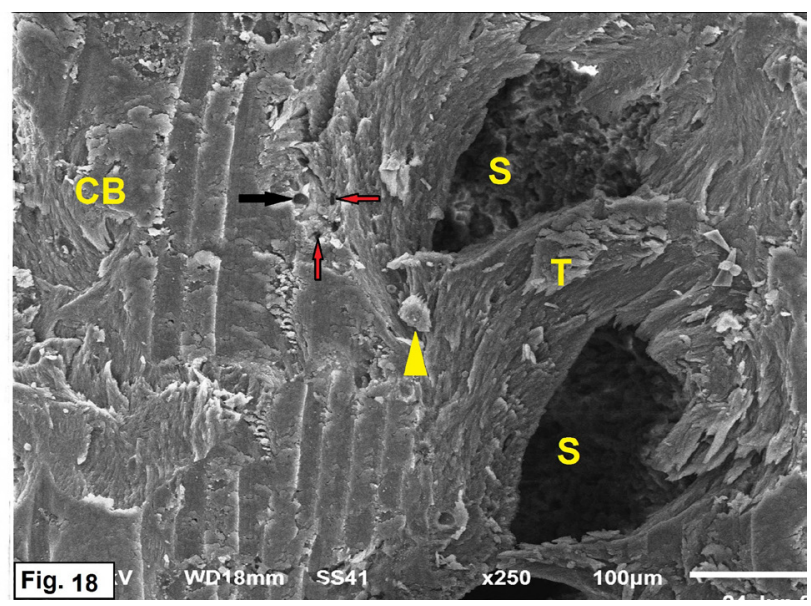

Fig. 18: A scanning electron micrograph of a guinea pig femur of group I (control group) showing cancellous bone trabeculae $(\mathrm{T})$ with bone marrow spaces $(\mathrm{S})$ inbetween arising from the outer cortical bone (CB)

Haversian canals (black arrow) surrounded by osteocyte lacunae (red arrows) are seen. Notice, osteoclast cells (arrowhead) with ruffled border facing bone surface.X250

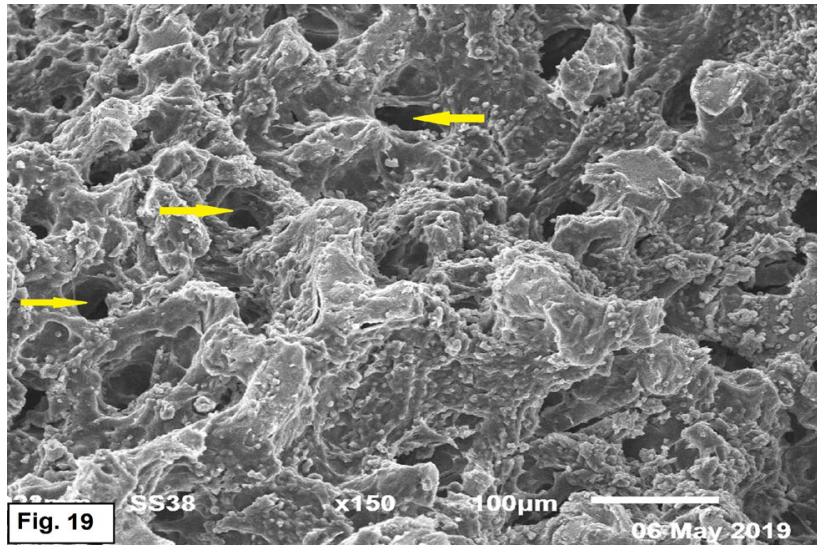

Fig. 19: A scanning electron micrograph of a guinea pig femur of group I (control group) showing endosteal surface with pores (arrows).X150

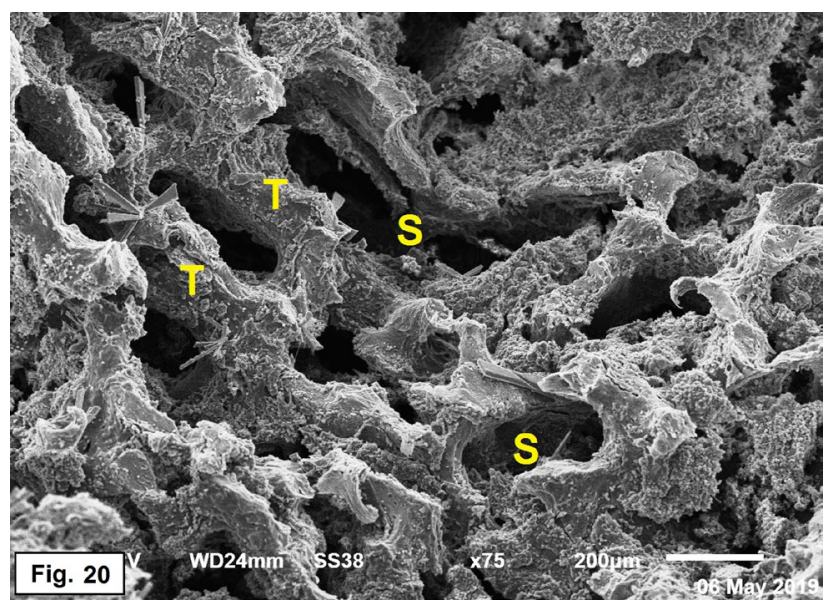

Fig. 20: A scanning electron micrograph of a guinea pig femur of group I (control group) showing branching and anastomosing cancellous bone trabeculae (T) with uniform size and bone marrow spaces $(\mathrm{S})$ inbetween X75

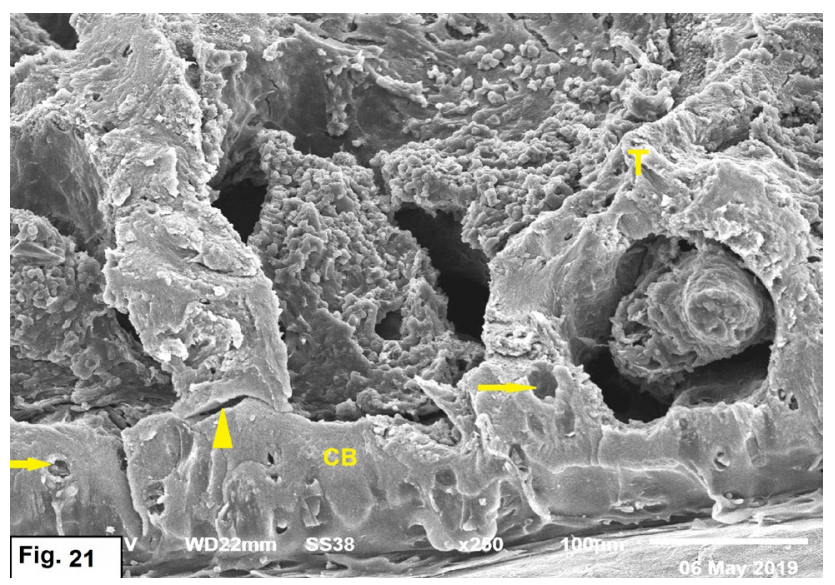

Fig. 21: A scanning electron microscope of a guinea pig femur of group III (valporic acid treated group) showing discontinous trabeculae (T) arising from apparently thin compact bone (CB) containing apparent widened haversian canal ( arrows). Notice, cracks in bone surface(arrowhead). $\mathrm{X} 250$ 


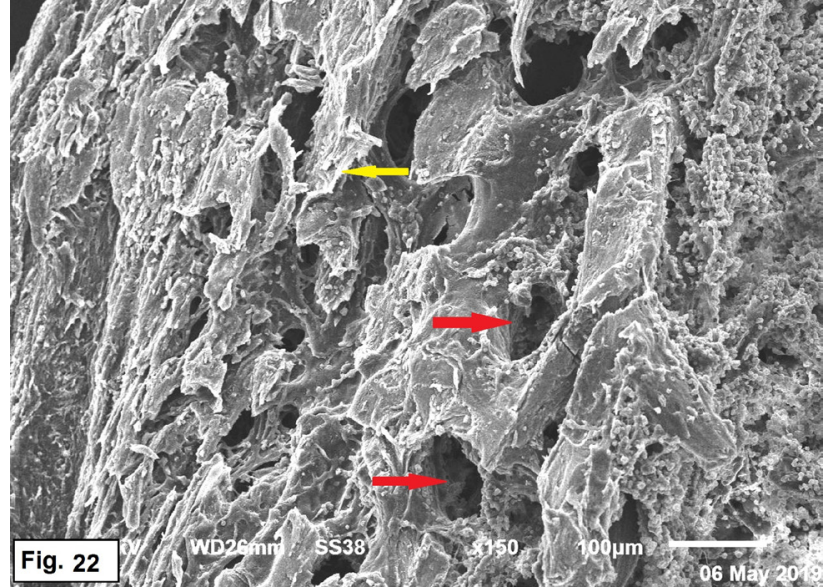

Fig. 22: A scanning electron microscope of a guinea pig femur of group III (valporic acid treated group) showing peeling (yellow arrow) of the endosteal surface with wide pores (red arrows).X150

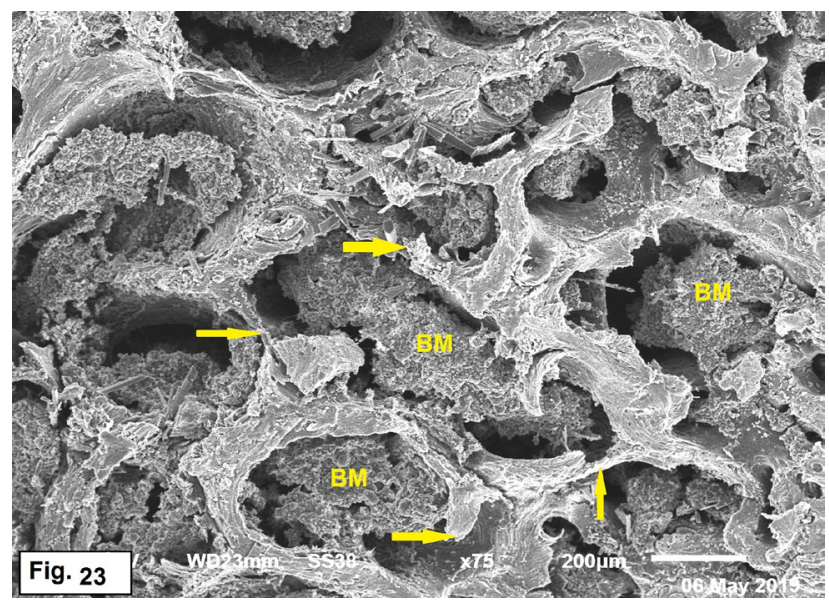

Fig. 23: A scanning electron micrograph of a guinea pig femur of group III (valporic acid treated group) showing thin and broken cancellous bone trabeculae (arrows) with loss of uniform thickness with bone marrow inbetween (BM). X75

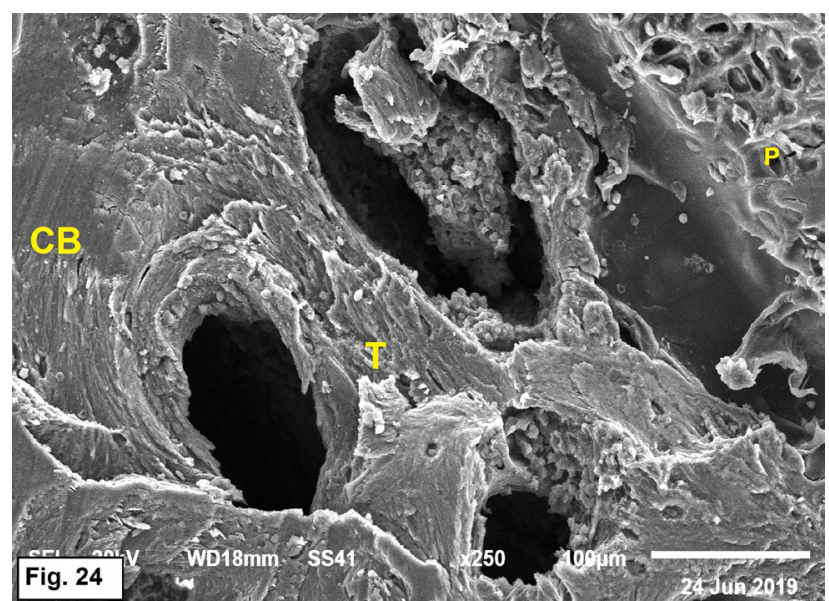

Fig. 24: A scanning electron micrograph of a guinea pig femur of group IV (L-carnitine and Valporic acid treated group) showing branching and anastomosing trabeculae (T) and cortical bone (CB) of uniform thickness. Notice, epiphyseal plate (P), X250

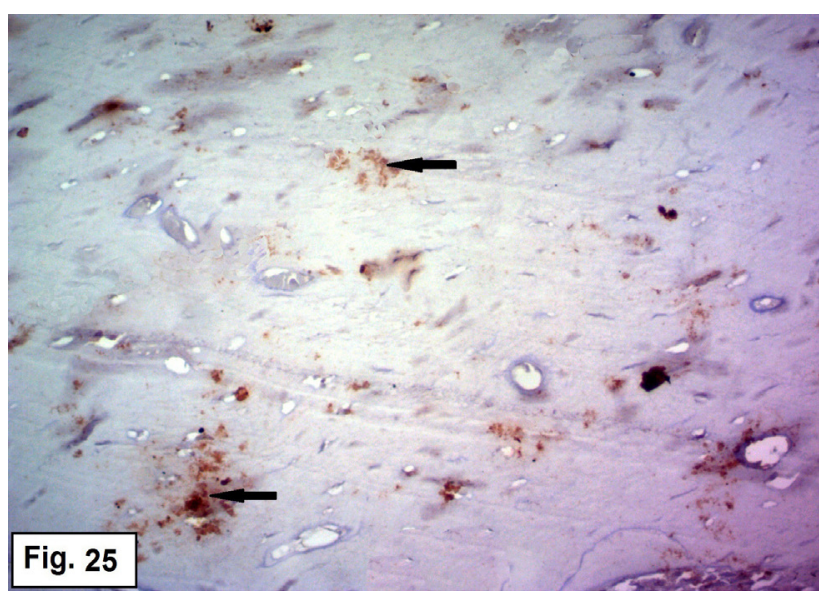

Fig. 25: A photomicrograph of a guinea pig femur of group I (control group) showing marked positive reaction of osteopontin protein, expressed as brown granules in bone matrix (arrows) and negative expression in the other bone components. OPNX400

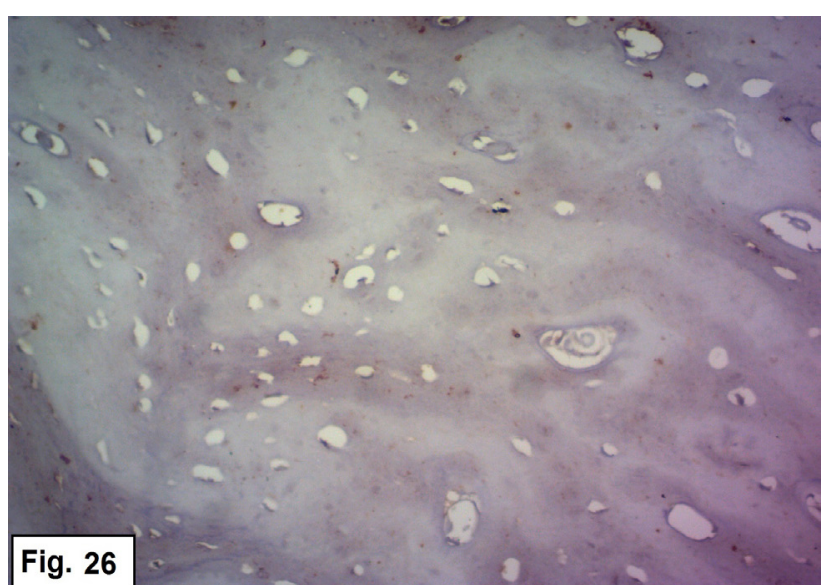

Fig. 26: A photomicrograph of a guinea pig femur of group III (valporic acid treated group) showing marked decrease in osteopontin expression in bone matrix.OPNX400

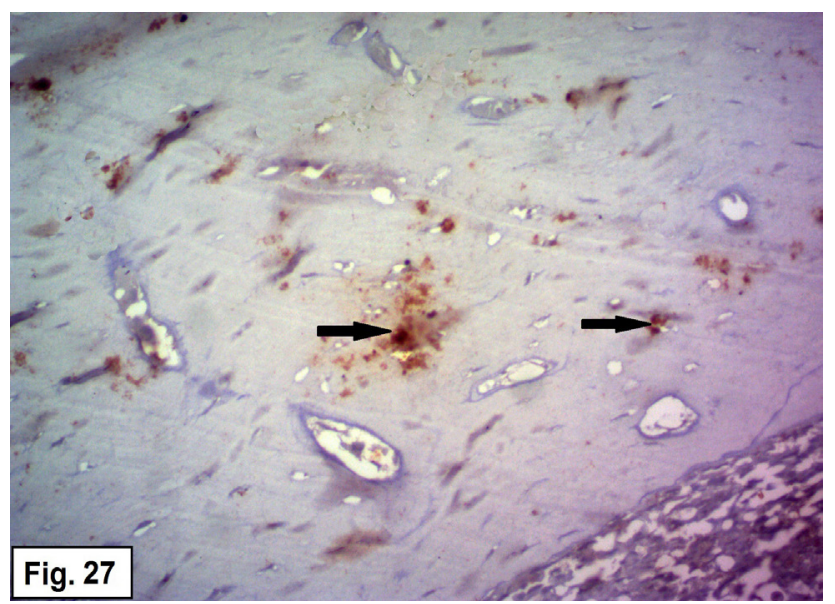

Fig. 27: A photomicrograph of a guinea pig femur of group IV (L-carnitine and valporic acid treated group) showing an increase in osteopontin brown immunoreaction in bone matrix (arrows) more or less as in control animals. OPN X400 


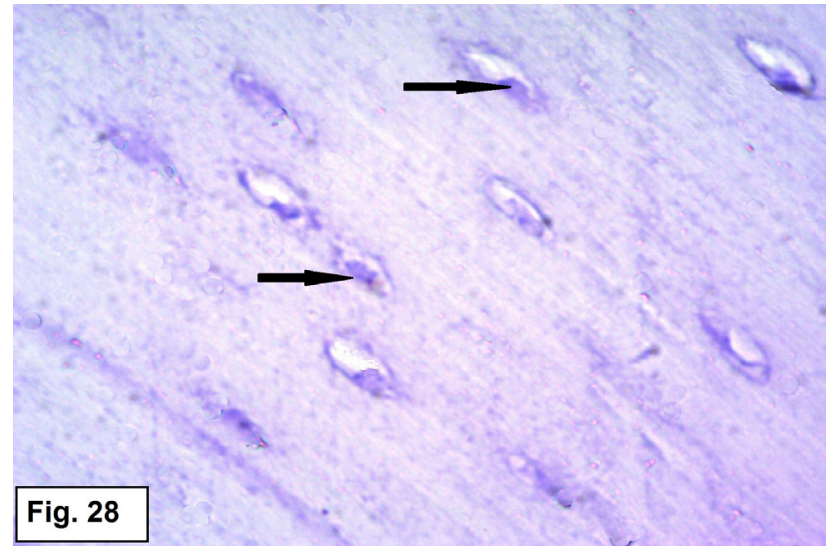

Fig. 28: A photomicrograph of a guinea pig femur of group I (control group) showing negative immunoreactivity for caspase-3 in osteocytes (arrows). Caspase-3 X1000

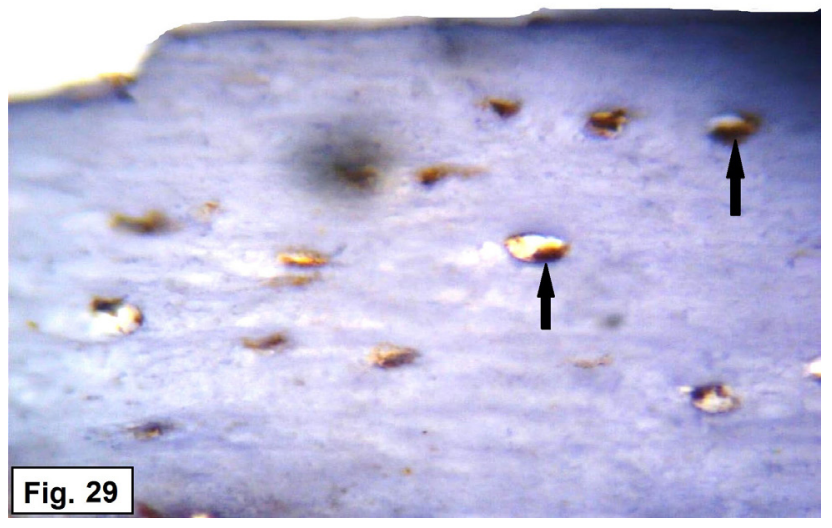

Fig. 29: A photomicrograph of a guinea pig femur of group III (valporic acid treated group) showing positive cytoplasmic immunoreactivity in the form of brown granules for caspase- 3 in osteocytes (arrows).Caspase$3 \mathrm{X} 1000$

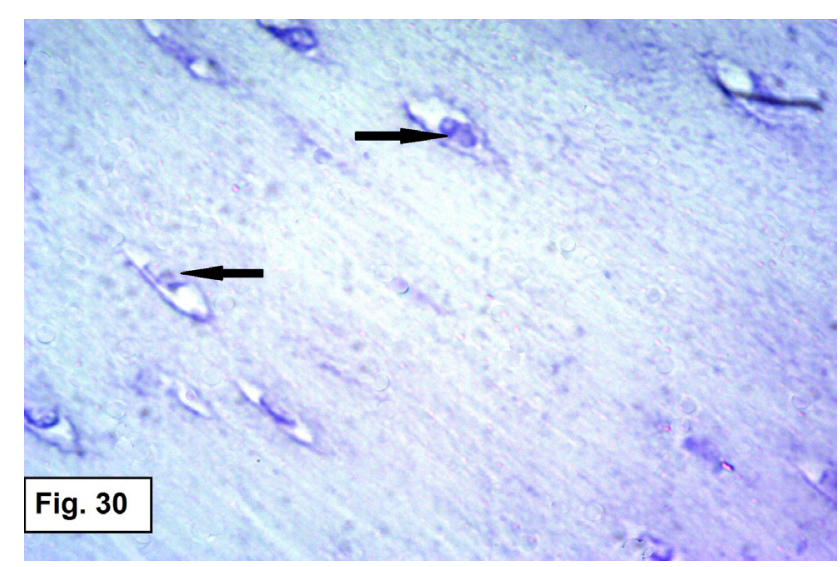

Fig. 30: A photomicrograph of a guinea pig femur of group IV (L- carnitine and valporic acid treated group) showing negative cytoplasmic immunoreactivity for caspase-3 in osteocytes (arrows). Caspase-3X1000

Table 1: Effect of valporic acid without and with L-carnitine on biochemical parameters in all groups of animals

\begin{tabular}{|c|c|c|c|c|c|}
\hline & $\begin{array}{c}\text { Group I } \\
\text { (Control group) } \\
\mathrm{M} \pm \mathrm{SD}\end{array}$ & $\begin{array}{l}\text { Group II(L-carnitine } \\
\text { treated group) } \\
\mathrm{M} \pm \mathrm{SD}\end{array}$ & $\begin{array}{c}\text { Group III } \\
\text { (Valporic acid treated group) } \\
\mathrm{M} \pm \mathrm{SD}\end{array}$ & $\begin{array}{c}\text { Group IV } \\
\text { (L-carnitine and Valporic } \\
\text { acid treated group) } \\
\mathrm{M} \pm \mathrm{SD}\end{array}$ & \\
\hline Serum calcium $(\mathrm{mmol} / \mathrm{ml})$ & $3.1 \pm 0.3$ & $3 \pm 0.1$ & $1.9 \pm 1.2$ & $2.9 \pm 0.1$ & $\begin{array}{c}\mathrm{P} 1=0.44 \\
\mathrm{P} 2=0.011 \\
\mathrm{P} 3=.091 \\
\mathrm{P} 4=0.024\end{array}$ \\
\hline Osteocalcin(ng/ml) & $19.7 \pm 0.2$ & $19.7 \pm 0.3$ & $11.8 \pm 2$ & $16.9 \pm 6$ & $\begin{array}{l}\mathrm{P} 1=0.712 \\
\mathrm{P} 2=0.000 \\
\mathrm{P} 3=0.151 \\
\mathrm{P} 4=0.020\end{array}$ \\
\hline TRAP (U/L) & $7.1 \pm 0.5$ & $6.7 \pm 0.6$ & $16.9 \pm 0.5$ & $6.6 \pm 0.6$ & $\begin{array}{l}\mathrm{P} 1=0.190 \\
\mathrm{P} 2=0.000 \\
\mathrm{P} 3=0.090 \\
\mathrm{P} 4=0.000\end{array}$ \\
\hline
\end{tabular}

$\mathrm{M}=$ the mean value. $\mathrm{SD}=$ the standard deviation.

P1 Comparison was done between group II (L-carnitine treated group) and group I (control group)

P2 Comparison was done between group III (valporic acid treated group) and group I (control group)

P3 Comparison was done between group IV (L-carnitine and valporic acid treated group) and group I (control group)

P4 Comparison was done between group IV (L-carnitine and valporic acid treated group ) and group III (valporic acid treated group) 
Table 2: Means and standard deviations of the number of osteoclast and osteoblast cells /high power field \& cortical bone and trabecular bone thickness in all experimental groups

\begin{tabular}{|c|c|c|c|c|c|}
\hline & $\begin{array}{c}\text { Group I } \\
\text { (Control group) } \\
\mathrm{M} \pm \mathrm{SD}\end{array}$ & $\begin{array}{l}\text { Group II(L-carnitine } \\
\text { treated group) } \\
\mathrm{M} \pm \mathrm{SD}\end{array}$ & $\begin{array}{c}\text { Group III } \\
\text { (Valporic acid treated group) } \\
\mathrm{M} \pm \mathrm{SD}\end{array}$ & $\begin{array}{c}\text { Group IV } \\
\text { (L-carnitine and Valporic } \\
\text { acid treated group) } \\
\mathrm{M} \pm \mathrm{SD}\end{array}$ & \\
\hline Osteoclast number/HPF & $0.7 \pm 0.1$ & $0.8 \pm 0.4$ & $6.9 \pm 0.6$ & $1.5 \pm 2.3$ & $\begin{array}{l}\mathrm{P} 1=0.488 \\
\mathrm{P} 2=0.000 \\
\mathrm{P} 3=0.290 \\
\mathrm{P} 4=0.000\end{array}$ \\
\hline Osteoblast number/HPF & $15.5 \pm 0.3$ & $15.3 \pm 0.4$ & $3.8 \pm 0.5$ & $14.6 \pm 1.7$ & $\begin{array}{l}\mathrm{P} 1=0.15 \\
\mathrm{P} 2=0.000 \\
\mathrm{P} 3=0.130 \\
\mathrm{P} 4=0.000\end{array}$ \\
\hline $\mathrm{CBT}(\mu \mathrm{m})$ & $642.6 \pm 3.8$ & $640.4 \pm 2.5$ & $530.2 \pm 32.2$ & $623 \pm 40.5$ & $\begin{array}{l}\mathrm{P} 1=0.131 \\
\mathrm{P} 2=0.000 \\
\mathrm{P} 3=0.154 \\
\mathrm{P} 4=0.000\end{array}$ \\
\hline TBT $(\mu \mathrm{m})$ & $162.3 \pm 2.4$ & $161.1 \pm 2$ & $111.5 \pm 3$ & $158.3 \pm 8.5$ & $\begin{array}{l}\mathrm{P} 1=0.228 \\
\mathrm{P} 2=0.000 \\
\mathrm{P} 3=0.166 \\
\mathrm{P} 4=0.000\end{array}$ \\
\hline
\end{tabular}

$\mathrm{M}=$ the mean value. $\mathrm{SD}=$ the standard deviation.

P1 Comparison was done between group II (L-carnitine treated group) and group I (control group)

P2 Comparison was done between group III (valporic acid treated group) and group I (control group)

P3 Comparison was done between group IV (L-carnitine and valporic acid treated group) and group I (control group)

P4 Comparison was done between group IV (L-carnitine and valporic acid treated group ) and group III (valporic acid treated group)

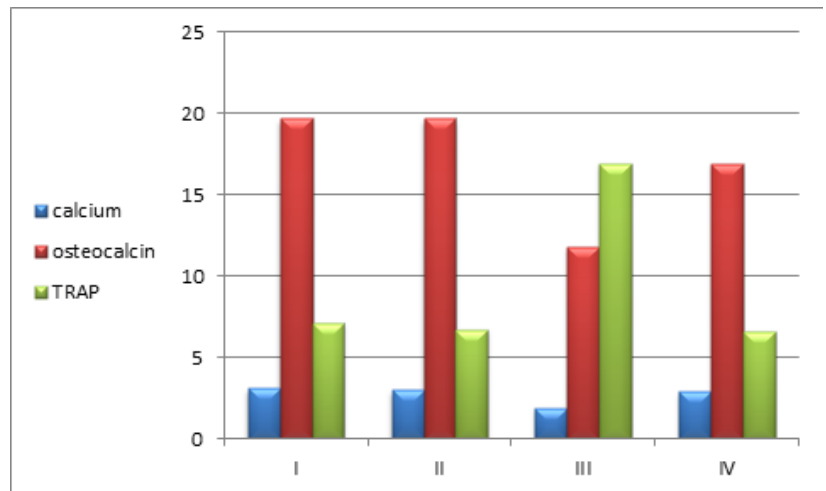

Histogram 1: The mean calcium, osteocalcin and TRAP levels in different experimental groups

\section{DISCUSSION}

The chronic use of AEDs is associated with increased risk of bone loss and fracture. Valporic acid (VPA) is one of AEDs influencing bone turnover ${ }^{[6]}$. In the current study, results were carried out to investigate the effect of valporic acid on bone mass and metabolism in adult male guinea pigs and the possible protective effect of L-carnitine. By observing the general appearance of animals during experiment, valproic acid treated group showed decreased activity and one guinea pig died, the most frequent adverse drug reactions of valproic acid include somnolence, fatigue and headache. The most serious adverse effects include hepatotoxicity and pancreatitis, both of which might be fatal, especially with long-term VPA treatment [5]. Regarding, the biochemical results of the valporic acid treated group, it exhibited enhanced bone turnover as

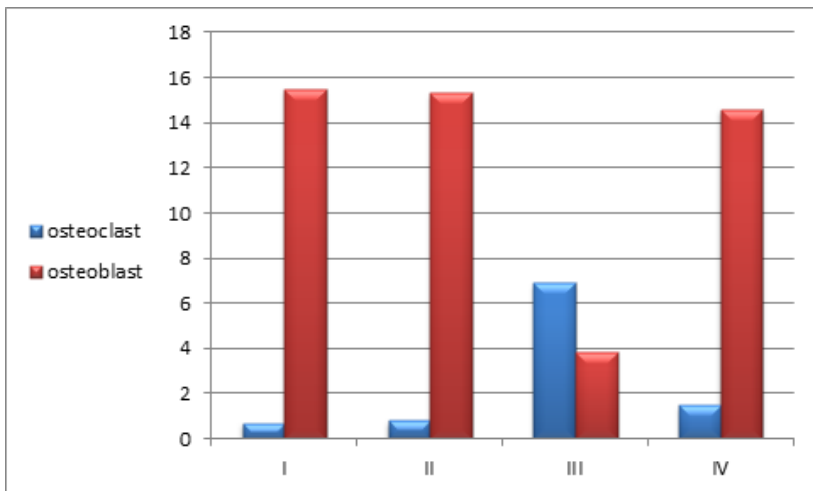

Histogram 2: The mean of the number of osteoclast and osteoblast cells in different groups

evident by a significant decrease in serum calcium and a highly significant decrease in osteocalcin (a marker of osteoblastic activity) and a highly significant increase in tartrate-resistant acid phosphatase (TRAP) (a marker of osteoclastic activity) compared with that of the control animals. These results were coincided with Verrotti et $a l .{ }^{[24]}$ who reported that increasing duration of AED treatment may decrease bone mineral density and elevate the risk of bone fracture, bone biochemical markers are indexes to evaluate the alteration of bone turnover.

Long term anti-epileptic therapy with VPA might lead to osteopenia ${ }^{[25]}$. Moreover, hypocalcemia might influence $40 \%$ of epileptic patients treated with $\mathrm{VPA}^{[26]}$.

It was found that, VPA induces hepatic cytochrome P450 enzymes, leading to degradation of vitamin D 
and decreased calcium absorption from the gut. Also, interference with renal activation and metabolism of vitamin D was reported ${ }^{[24]}$. Deficiency of vitamin D is correlated with rickets in children and osteomalacia in adults and both of these have been reported in VPA treated patients. Hypocalcemia leads to secondary hyperparathyroidism and increased bone turnover ${ }^{[27]}$. In addition, the morphometric study revealed an increase in osteoclast and decrease in osteoblast numbers per area of bone surface of the upper part of femur.

These results were in accordance with those of other investigators who stated that VPA caused decrease in bone mass $^{[28]}$. So, long term administration of VPA could cause osteopenia due to bone resorption acceleration and inhibition of bone formation. Also, in osteoporosis, there was increase in oxidative stress enzymes such as malondialdehyde (MDA) that might be due to increase in the osteoclast activity ${ }^{[29]}$. Moreover, Kim et al.$^{\left[{ }^{[0]}\right.}$ described a relation between oxidative stress and osteoporosis. They stated that Reactive oxygen Species (ROS) could be relevant to osteoclast differentiation.

Furthermore, the light microscopic results is confirmed by morphometric study in the current study and exhibited a highly significant decrease in the cortical bone and trabecular bone thickness as compared with the control group. Degeneration of osteocytes with pyknotic nuclei and even empty lacunae, were observed in this study. Some studies found that VPA affects development of osteocytes resulting in their death ${ }^{[31]}$. Cement lines that separate the newly formed bone from the old one appeared irregular, and attributed to an increase in bone resorption rate over that of bone formation ${ }^{[32]}$. Cancellous trabecular bone were observed with eroded area, some areas of pale staining appeared because of decreased bone density, while, other trabeculae appeared thinned out. Similarly, Lane et al[33] described osteoporosis as a syndrome of excess skeletal fragility that occurred due to decrease in trabecular bone mass and connectivity. Bone metabolism is the combination of bone formation by osteoblasts and bone resorption by osteoclasts. Increase in bone resorption is considered the essential factor of bone loss that lead to osteoporosis ${ }^{[34]}$.

In the current study, SEM examination of valporic acid treated group revealed thinning and broken trabeculae arising from apparently thin compact bone containing apparent widened haversian canal. This was in agreement with the findings of other authors ${ }^{[28]}$ after AEDs treatment. Similar results were also described by some studies who reported that in severe cases of osteoporosis, the haversian canals were so widened. It was reported that, first, osteoclastic resorption with subsequent enlarging of the haversian canals appeared in the inner parts of the cortical bone and then, gradually emerged over the central part of the cortical bone $\mathrm{e}^{[35]}$.

In the current study, mallory trichrome stained sections showed reduced amount of collagen fibers. This result is in accordance with Rishikoof et al. ${ }^{[36]}$ who reported that pro- collagen I level is significantly down-regulated by VPA therapy of cultured undifferentiated osteoblast cells. Some studies reported the effect of AEDs in decreasing formation of collagen I mRNA in lung fibroblasts ${ }^{[37]}$. The decrease in collagen fibers leads to increase in bone fragility and tendency to fracture associated with VPA therapy ${ }^{[38]}$.

In this study, immunostaining results revealed that VPA administration caused positive cytoplasmic caspase-3 immunoreactivity in osteocytes. Some studies described the effects of VPA on the proliferation of cultured growth plate chondrocytes in vitro and revealed that inhibition of cell proliferation by $\mathrm{VPA}^{[39]}$. Also, it was reported that, valproic acid delays the progression of cell-cycle and induces apoptosis, thereby leading to prevention of cell growth and proliferation ${ }^{[31]}$. A significant increase in RANKL levels (Osteoclast activating factor), indicating increased bone turnover was reported with the chronic use of $\mathrm{VPA}^{[40]}$.

Bone sections from valporic acid treated group revealed marked decrease in osteopontin (OPN) expression in bone matrix. Osteopontin has been interpreted as a bone formation indicator. OPN is formed via osteoblatic cells at different stages of differentiation and accumulates in mineralized bone matrix. It could be important for cellmatrix interaction. Osteopontin plays multiple roles in bone formation, resorption and remodeling ${ }^{[4]}$.

In this work, Administration of L-carnitine with valporic acid improved serum calcium, osteocalcin and TRAP in group IV. Moreover, L-carnitine improved morphometric, histological, immunohistochemical and scanning electron microscopic results

The protective effects of L-carnitine have been described in multiple studies. L- carnitine is a natural endogenous quaternary ammonium compound that have an important effect in inducing mitochondrial $\beta$-oxidation inhibiting free fatty acid- induced oxidative stress ${ }^{[42]}$. The antioxidant activity of L-carnitine was reported. It was found that L- carnitine assists transport of long-chain fatty acids into mitochondria for $\beta$-oxidation and thus controls the quantity of energy available for protein synthesis in osteoblasts. Furthermore L-carnitine increased osteoblast activity and decreased bone loss in elderly ${ }^{[33]}$ and improve bone structure by decreasing bone turnover ${ }^{[44]}$. L-carnitine administration resulted in significant increase of antioxidant enzymes as catalase, glutathione peroxidase and superoxide dismutase, it has a role in chelating free iron ions and so, might decrease free radical generation. Scavenging of Reactive Oxygen Species (ROS) is estimated by antioxidant enzymes such as SOD and CAT ${ }^{[45]}$.

L-carnitine administration leads to a significant decrease in serum malondialdehyde due to increasing phospholipids synthesis required for membrane formation and integrity ${ }^{[4]}$. It might prevent cell damage by stabilizing the membrane against free radical-induced injury and also could prevent mitochondrial injury and so, energy production is increased with reducing the free radicals leakage ${ }^{[47]}$ 
Recently, 1-carnitine was found to stimulate production of nitric oxide $(\mathrm{NO})^{[48]}$. The increased $\mathrm{NO}$ has been found to influence BMD and increased serum estradiol level, protecting against osteoporosis ${ }^{[49]}$. It was recommended to use L-carnitine in concurrent with long term administration of valporic acid.

\section{CONFLICTS OF INTEREST}

There are no conflicts of interest

\section{REFERENCES}

1. Hamed SA, Moussa EM, Youssef AH, Abd ElHameed MA, NasrEldin, E. (2014): Bone status in patients with epilepsy: relationship to markers of bone remodeling. Front. Neurol. 5-142.

2. Fisher R, Van Emde Boas W, Blume W, Elger C, Genton P, Lee P, Engel J. (2005): Epileptic seizures and epilepsy: definitions proposed by the International League Against Epilepsy (ILAE) and the International Bureau for Epilepsy (IBE). Epilepsia . 46(4):470-2.

3. Terbach N and Williams RS. (2009): Structurefunction studies for the panacea, valporic acid. Biochem. Soc. Trans. 37, 1126-1132.

4. Ghodke-Puranik Y, Thorn CF, Lamba JK, Leeder JS, Song W, Birnbaum AK, Altman RB, Klein TE. (2013): "Valproic acid pathway: pharmacokinetics pharmacodynamics". Pharmacogenet. Genomics. 23 (4): 236-241.

5. Spiller HA, Krenzelok EP, Klein-Schwartz W, Winter ML, Weber JA, Sollee DR, BanghSA, Griffith JR. (2000): Multicenter caseseries of valporic acid ingestion : serum concentrations and toxicity. J Toxicol Clin Toxicol, 38:755-760.

6. Pack AM, Gidal B, Vazquez B. (2004): Bone disease associated with antiepileptic drugs. Cleve Clin J Med 71 (suppl 2):s42-s48.

7. Stanley CA. (2004). "Carnitine deficiency disorders in children". Annals of the New York Academy of Sciences. 1033: 42-51.

8. Rebouche CJ. (1999): Modern Nutrition in Health and Disease (9th ). New York. Lippincott Williams \& Wilkins. PP. 505-12.

9. Tars, Kaspars, Rumnieks, Janis, Zeltins, Andris, Kazaks, Andris, Kotelovica, Svetlana, Leonciks, Ainars, Sharipo, Jelena, Viksna, Arturs, Kuka, Janis.( 2010). "Crystal structure of human gammabutyrobetaine hydroxylase". Biochemical and Biophysical Research Communications. 398 (4): 634-639..

10. Colucci S, Mori G, Vaira et al., (2005): L-carnitine and isovaleryl L-carnitine fumarate positively affect human osteoblast proliferation and differentiation in vitro, Calcified Tissue International, vol. 76,no.6,pp. 458-465.
11. Hooshmand S, A. Balakrishnan R.M, Clark K.Q, Owen S.I. (2008): Dietary 1-carnitine supplementation improves bone mineral density by suppressing bone turnover in aged ovariectomized rats. Phytomedicine, 15: 595-601.

12. Benedini S, Perseghin I, Terruzzi et al., (2009): Effect of L-acetylcarnitine on body composition in HIV-related lipodystrophy' Hormone and Metabolic Research, vol. 41,no. 11,pp.840-845.

13. Curtis M. (2016): The in vitro isolated whole guinea pig brain as a model to study epileptiform activity patterns. J Neurosci Methods.260, 83-90.

14. Vardar SA, Gunduz O, Altun GD, Aydogdu N, Karadag H, Torun N, Kaya O. (2011): The alteration of asymmetric dimetilarginine (ADMA) levels in cardiac and gastrocnemius muscles following radioactive iodine application in guinea pigs and the effect of $\mathrm{L}$ - carnitine on this alteration. Int J Radiat Biol. ;87(1):2-7.

15. Trevvor H, Campbell T. (2007): Conventional anticonvulsant drugs in the guinea pig kindling model of parial seizures: effects of repeated administration. 178(1):115-125

16. Gowenlock AH, Mc Muray JR, Mc Lauchlaan DM. (1988):.Varley's practical clinical biochemistry 6th ed. London, UK:William Heinemann Medical Books Ltd;612-618.

17. Power MJ and Fottrell PF. (1991): Osteocalcin, diagnostic methods and clinical applications.Crit Rev Clin Lab Sci;28:287-295.

18. Ljusberg J, Ek-Rylander B, Andersson G. (1999). "Tartrate-resistant purple acid phosphatase is synthesized as a latent proenzyme and activated by cysteine proteinases". Biochem. J. 343 (1): 63-9.

19. Bancroft JD and Layton, C. (2010): Theory and practice of histological technique, 7th ed., London: Churchill Livingstone. P 173-214.

20. Fujita T, Tanaka K, Tokunaga J. (1981): Scanning electron microscopy, atlas of cells and tissues. 1st ed. Tokyo, New York: Igaku-Shoin.

21. Wang YP and Liu BY. (2009): High expression of osteopontinandCD44v6inodontogenickeratocysts. J. Formos. Med. Assoc.;108(4):286-292.

22. Sanni S, Saffar H, Tabriz HM, Qarbani M, Haghpanah V, Tavangar SM. (2012): Asian Pac. J. cancer Prev., 13:2175-2167.

23. Peat, J and Barton, B. (2005): Medical statistics. A Guid to data analysis and critical appraisal. First ed., Wiley-Blackwell.113-19.

24. Verrotti A, Agoostinelli S, Coppola G, Parisi P, Chiarelli F. (2010): A 12 -month longitudinal study of calcium metabolism and bone turnover during valproate monotherapy. Eur J Neurol 17:232-7. 
25. Pack AM, Morrell MJ, Marcus R, Holloway L, Flaster E, Done S et al. (2005): Bone mass and turnover in women with epilepsy on antiepileptic drug monotherapy. Ann Neurol;57(2):252-7.

26. Kumandas S, Koklu E, Gumus H, Karakukcu M et al. (2006): Effect of carbamezapine and valporic acid on bone mineral density. IGF-I and IGFBP-3. J Pediatr Endocrinol Metab. 19(4):529-34.

27. Pack AM, Gidal B, Vazquez B. (2004): Bone disease associated with antiepileptic drugs. Cleve Clin J Med, 71 (Sippl 2):S42-S48.

28. Nissen-Meyer LS, Svalheim S, Reppe S, Lekva T, Solberg LB, et al. (2007): Levetiracetam, phenytoin, and valproate act differently on rat bone mass, structure and metabolism. Epilepsia;48:1850-1860.

29. Chavan SN, More U, Mulgynd S, Saxena V, Sontakke AN. (2007): Effect of supplementation of vitamin $\mathrm{C}$ and $\mathrm{E}$ on oxidative stress in osteoporosis. Indian J Clin Biochem;22:101-105.

30. Kim HJ, Chang EJ, Kim HM, Lee SB. (2006): Antioxidant alpha-lipoic acid inhibits osteoclast differentiation by reducing nuclear factor Kappa B DNA binding and prevents in vivo bone resorption induced by receptor activator of nuclear factorkappaB ligand and tumor necrosis factor -alpha. Free Radic Biol Med;40:1483-1493.

31. Vallo S, Xi W, Hudak L, Juengel E, Tsaur I, Wiesner C, Haferkamp A. (2011): HDAC inhibition delays cell cycle progression of human bladder cancer cells in vitro. Anticancer Drugs,22:1002-1009.

32. Seeman E. (2002): Pathogenesis of bone fragility in women and men. Lancet; 359:1841-1850.

33. Lane NE, Yao W, Kinney JH, Modin G, Balooch M. (2003): Both hPTH and bFGF increase trabecular bone mass in osteopenic rats but they have different effects on trabecular bone architecture. J Bone Miner Res; 18:2012115.

34. Meier C and Kraenzlin ME. (2011): Antiepileptics and bone health. The Adv Musculoskelet Dis 3, 235-243.

35. Chai B, Tang X, Tan Z. (1995): Osteoclastic resorption Of Haversian system of femoral neck cortex in aged women. Zhonghua Wai Ke Zhi; 33:313-315.

36. Rishikof D.C, Ricupero, D.A, Liu H, Goldstein R.H. (2004): Phenylbutyrate decreases type I collagen prpduction in human lung fibroblasts. J. cell Biochem. 91,740-748.

37. Fuller, H.R., Man, N.T., Lam T., Shamanin, V.A., Andr0phy, E.J., Morris, G.E. (2010): Valproate and bone loss: ITRAQ proteomics show that valproate reduces collagens and osteonectin in SMA cells. J. proteome Res. 9, 4228-4323.
38. Lee, R.H., Lyles, K.W., Colon-Emeric, C. ( 2010): A review of the effect of anticonvulsant medications on bone mineral density and fracture risk. Am. J. Geriatr. Pharmacother. 8,34-46.

39. Zhang CL, Mckinsey TA, Olson E.N. (2002): Association of class II histone deacetylases with heterochromatin proten 1: potential role for histone methylation in control of muscle differentiation. Mol Cell Biol, 22:7302-7312.

40. Bushra P, Ambrish K, Moon J, Subhashis P, Naibedya C et al. (2018) : The anti-epileptic drugs valproate, carbamazepine and levetiracetam cause bone loss and modulate Wnt inhibitors in normal and ovariecomised rats. Bone 113; 57-67.

41. Wang KX, Denhardt DT. (2008): Osteopontin rol in immune regulation and stress response. Cytokine Growth Factor Rev. 2008;19(5)-6:333-45.

42. Jun, DW, Cho, W.K, Jun, J.H. et al. (2011): Prevention of free fatty acids-induced hepatic lipotoxicity by carnitine via reversal of mitochondrial dysfunction Liver Int., 31(9):1315-1324.

43. Glucci S., Mori G, Vaira S, et al. (2005): L-carnitine and isovaleryl L-carnitine fumarate positively affect human osteoblast proliferation and differentiation in vitro. Cal-cif. Tissue Int., 76(6):458-465.

44. Hooshmand, S., Balakrishnan, A., Clark, R.M., et al. (2008): Dietary L-carnitine supplementation improves bone mineral density by suppressing bone turnover in aged ovariectomized rats. Phytomedicine, 15(8):595-601.

45. Datta, k., Sinha, S. and Chattopadhyay, P. (2000): Reactive oxgen species in health and diseases. Nat. Med J India, 13:304-10.

46. Kashiwagi A, Kanno T, Arita K, Ishisaka R, Utsumi T, Ytsumi, K. (2001): Suppression of T (3)-and fatty acid- induced membrane permeability transition by L- carnitine. Comp Biochem Physiol B Biochem Mol Biol, 130:411-418.

47. Binienda Z, Johnson J.R, Tyler-Hashemi, A.A, Rountree R.L, Sapienza P.P.et al. (1999): Protective effect of L- carnitine in the neurotoxicity induced by the mitochondrial inhibitor 3-nitropropionic acid (3-NPA). Ann N Y Acad Sci, 890:173-178.

48. Ning W.H, Zhao K. (2013): Propionyl-L-carnitine induces eNOS activation and nitric oxide synthesis in endothelial cells via PI3 and Akt kinases. Vascul. Pharmacol., 59(3-4):76-82.

49. Liu S.Z, Yan H, Hou W.K. et al. (2009): Relationships between endothelial nitric oxide synthase gene polymorphisms and osteoporosis in postmenopausal women. J. Zhejiang Univ-Sci. B, 10(8):609-618 


\title{
الملخص العربى
}

\section{دراسه هستولوجيه وهستوكيميائيه على تاثير حمض الفالبورك على عظم فخذ خنازير

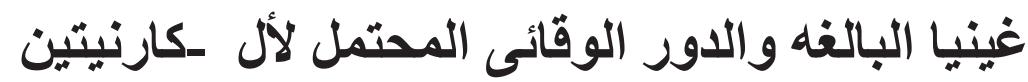

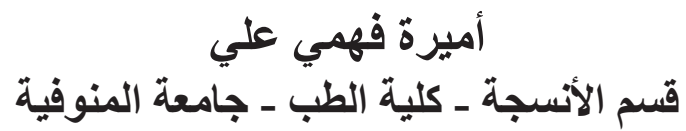

المقدمه: حمض الفالبورك هو دواء مضاد للصرع وهوفعال فى علاج انواع مختلفه من نوبات الصرع. ويتعرض المرضى الذين يتناولون هذه الادويه لانخفاض كثافة المعادن في العظام وزيادة مخاطر الكسور. إلـ كارنيتين من المكملات الغذائية وله تاثير ات وقائيه محتمله للعظام ويعزز استخدام الطاقه وهمج للانسجه ذات متطلبات الطاقه العاليه. الهدف من البحث: تقييم تأثير حمض الفالبوريك على عظم الفخذ والتأثير الوقائي المحتمل إل- ـكارنبتين في خنازير غينيا البالغة.

الطرق المستخدمه: تم استخدام اربعين حيوان في هذه الدراسة. وقد قسموا إلى أربع مجمو عات، المجموعة الأولى الضابطة، المجمو عة الثانية المعالجة ب أل-كارنبتين، المجمو عه الثالثه المعالجة بحمض الفالبورك و المجموعة الر ابعة المعالجة ب ألكارنيتين وحمض الفالبورك. بعد · 1 أسابيع، تمت معالجة الاجزاء العليا من عظم الفخذ للاراسات

$$
\text { النسيجية والمورفولوجية و المناعية. }
$$

النتائج: أظهرت مجموعة حمض الفالبورك انخفاضًا كبيرًا في مستويات الكالسيوم و الأوستوكالسين (علامه لنشاط الخلايا بانية العظم) فى الدم. بينما أظهرت زيادة في مستويات ت.ر.ب. (علامه لنشاط الخلايا ناقصة العظم). و علاوة على ذلك، كان هناك انخفاض كبير للغاية في سمك العظام المسامى و القشرية، وتغير كبير فى منوسط عدد الخلايا البانيه و الناقصه للعظم. بالإضافة إلى التغير ات النسيجية، قد اظهرت النتائج وجود تجاويف متعددة مع انخفاض الياف الكو لاجين فى عظام الفخذ. و اظهرت هذه المجموعه مناعيه ايجابيه لالكسباس-؟ فى الخلايا العظميه و انخفاض فى الاوستوبنين فى العظم. مكملات الأل-كارنيتين مع حمض الفالبورك له دور وقائى فعال وقد اكد التحليل الاحصائى كل

$$
\text { النتائج السابقه. }
$$

الخلاصة: إلكارنيتين حسنت التتغير ات النسيجيه، المناعيه و المورفولوجيه التى يسبيها حمض الفالبورك. 